Open Access

\title{
The Buddha and the numen: postmodern spirituality and the problem of transcendence in Buddhism
}

\author{
Dan Lee(D)
}

Correspondence:
dan.cartwright.lee@gmail.com
College of Religious Studies,
Mahidol University, Salaya,
Phutthamonthol 4, Nakhorn
Prathom 73170, Thailand

Correspondence: dan.cartwrightlee@gmai.com Mahidol University, Salaya, Prathom 73170, Thailand

\begin{abstract}
The Western world has seen a significant shift in the epistemic values of spiritual seekers in the past quarter of a century; many have referred to the new epistemic approach as postmodern spirituality. Among the attributes unique to this growing cultural force are the prominence of mystery, enchantment, and the prehension of a numinous other (which need not be a theistic other) as key means of both valuing and validating any system of belief and practice. But postmodern spirituality is not the syncretism of New Age religion; its adherents seek an authentic path, not an eclectic, superficially fused path. How will Buddhism fare in the face of this new phenomenon? Much depends on whether Buddhism is understood by postmoderns to contain mystery, ineffability, and transcendence. Buddhism's first two centuries of significant contact with the West have occurred in the shadow of Western Enlightenment, modernity. Concurrent with this fact, and probably in response to it, there has been a Buddhist apologia which demystifies Buddhism. But desacralized religion, along with the other hallmarks of modernity—scientism, individualism, materialism, and rationalism - are precisely the cultural elements to which postmodern spirituality is a reaction. This piece argues that historical Buddhism does, in fact, contain transcendence and mystery and that it is quite capable of taking a seat at the open table of postmodern spirituality. The analysis applies a predominantly Eastern hermeneutic and examines relevant sacred texts alongside the arguments of both Eastern and Western scholars, pro and con.
\end{abstract}

\section{Background: the epistemic shift that is postmodern spirituality}

Postmodern spirituality (as distinct from philosophical, deconstructive postmodernism) is now roughly a quarter of a century old and continues to gain momentum as a significant Western cultural force (Benedikter and Molz 2012, Raschke 2008). ${ }^{1}$ Griffin has titled this form of postmodernism, "constructive postmodernism" (Griffin 1990, p. xi), a name that has caught on in many sectors. John Cobb suggests this new spirituality may become the dominant Western cultural dynamic of the twenty first century (Cobb 2002). All major branches of Christianity have been forced to come to grips with it in some degree, but the movement is much broader than Christianity (Raschke 2008). It is instead a wide epistemic shift. The age of the rational religious apologists is being swept aside and replaced with an age in which the persuasive "arguments" for any spiritual belief system are rooted more in numinous consciousness and ethical

(c) The Author(s). 2016 Open Access This article is distributed under the terms of the Creative Commons Attribution 4.0 International License (http://creativecommons.org/licenses/by/4.0/), which permits unrestricted use, distribution, and reproduction in any medium, provided you give appropriate credit to the original author(s) and the source, provide a link to the Creative Commons license, and indicate if changes were made. 
authenticity. The intuition or sensation of a numinous reality has become a key authenticator of faith and praxis. By "authenticator" I refer to any attribute or artifact of a spiritual system, leader or community which, in the psyche of the seeker, tends to stamp a teaching, practice or worldview as dharma-as true, authentic or effective. Such authenticators strike largely in the subconscious and may include intuition, emotion, encounter, experience, cultural authorities, intellect, habituation, and other influences. For postmodern spirituality the emphasis is decidedly on the first three or four-intuition, encounter, experience, emotion-the extra-rational authenticators. Not surprisingly, it is these that are most heavily involved in apprehension of the numen.

For the postmodern spiritual seeker there is ordinarily a second significant authenticator as well. A well-founded belief system must conform to a deep, sub-religious intuition of cosmic goodness and rightness. For the postmodern, rather than defining ethics within a particular religious/spiritual path, an ethical principle is felt to exist as an element of a universal, intuitive fabric (although its detailed implementation will always require discussion and debate; Griffin 1988, p. 17). If a spiritual path is authentic, it must conform to this universal ethos.

This fact should make evident that, unlike deconstructive postmodernism, spiritual or constructive postmodernism does not reject the idea of meaningful worldviews. Postmodern spirituality is, above all, driven by the reactionary worldview that the science, materialism and individualism of Western Enlightenment cannot address the deepest human yearnings (Griffin 1988). It seeks instead to restore mystery and connectedness to spiritual life and practice and has brought with it a robust, renewed interest in the religious mystics of the past (Griffin 1988, 1990) ... with minimal concern for the tradition in which they might have been situated. What the age of science sought to demystify, postmodern spirituality seeks to re-mystify. Postmodern spirituality should not be confused with New Age, for its interest in hearing these individual voices is not so that they may be syncretized. It is not seeking to form them collectively into a new religion which distorts or glosses over the distinctives ${ }^{2}$ of each in an attempt to unify them as if they were a single voice. On the contrary, postmodern spirituality celebrates the uniqueness of each voice (Cobb 2002) — and does not pretend that their truth claims are similar or compatible.

In its quest for mystery and authenticity, constructive postmodernism is eager to hear the voices of those whose worldview has been marginalized by the "grand narrative" of Western culture; this includes Buddhism. As a consequence thereof, an intriguing strand of postmodern spirituality has been embraced by Chinese neo-Guoxue (traditional culture) social activists who seek to renew a sacred, deeply earth- and human-caring ethic as Chinese progress matures (Tang 2015; Fan and Wang 2012). Nevertheless, the new spirituality remains a predominantly Western phenomenon.

So where does Buddhism currently stand in relation to this new spirituality? First, Buddhist ethics are a fairly solid match for the deep, overarching ethic of postmodern spirituality. But Buddhism struggles to address the other foundational value of postmodern spirituality - the restoration of mystery, of an ineffable, transcendent domain which has the capacity to enchant and inspire us; to influence our intentions, thoughts, and actions; and to interconnect us. We will employ the shorthand, "numen," for this transcendent domain, a use of the word devised by Rudolph Otto in his masterwork The Idea of the Holy (1917, translated into English in 1958). Otto's description of the numen as mysterium tremendum is a touchpoint which makes the designation especially relevant for adherents of 
postmodern spirituality. By mysterium Otto intended to convey (consistent with the Latin) both hiddenness and resistance to linguistic description and rational comprehension; by tremendum he meant that the numen has the capacity to enchant and awe us. (As a linguistic note, I should make clear that "transcendence" and "numen" are, for the most part, used interchangeably in this analysis. While the denotations of the two are distinct, it is ordinarily the case that that which transcends the mundane is also mysterium tremendum. In those few circumstances in which the denotation needs to be pressed, the analysis will give due consideration.)

\section{Methodology}

It is the labor of this brief work to make the case that Buddhism possesses a meaningful, if exceptionally unique, numen (at least in comparison to theistic numena) ... and that as a consequence Buddhism is a path consistent with postmodern spiritual values-and Gautama Buddha is a mystic appropriate to postmodern spiritual inquiry. The analysis proceeds by evaluating both canonical Buddhist texts and the statements of Buddhist scholars concerning transcendence. In dealing with the canonical sources, the analysis assumes a hermeneutic of doctrinal intent and straightforward linguistic meaning. While there was a late twentieth century effort to define Buddhism as method alone-as a system of praxis without doctrinal content, a system whose narratives are more moral parable than history and metaphysics (e.g. Stephen Batchelor, Buddhism without Beliefs, 1997)—such an approach is decidedly not the hermeneutic of Eastern Buddhism (Bodhi 1998).

This study begins by examining the question of whether Buddhism contains a doctrinally supported concept of a numinous. It then moves on to consider whether there is a de facto, practical numen, even if there is no clear "theological" (or dharmalogical) numen in some sectors of Buddhism. Interwoven throughout is a brief consideration of whether the Buddha was a mystic in this context ... at least as postmodern spirituality would define "mystic." For the purposes of our postmodern evaluation of the Buddha's praxis, mysticism may be understood as any direct, extra-rational, extra-sensory prehension of a numen. Such prehension ordinarily takes the form of altered states of consciousness and may be either hyper-arousing or hypo-arousing, or something in between ... despite the current academic preference for hypo-arousal as a defining feature of the mystical state.

\section{The question of ontological transcendence in Buddhism}

Some Buddhist scholars, both Eastern and Western, assert that the notion of a numen is conceptually misplaced when applied to Buddhism. It is difficult to trace the precise historical circumstances which gave rise to these assertions. We can, however, note the broad cultural conditions at the time these apologetics were offered. The denial of a numen in Buddhism was chronologically associated with the Buddhist encounter with the West-an encounter which occurred well after the West was already deeply entrenched in modernity, in the epoch of science, empiricism and reason. Bhikkhu Bodhi seems to expressly link the two. While not specifically addressing notions of transcendence or numen, he considered the Western tendency to desacralize Buddhism an artifact of the skepticism of modernity (Bodhi 1998). As Armstrong points out, science was especially loathe to embrace the idea of mysterion-ineffable religion. (Armstrong 2009) Buddhism, with its lack of a creator-god and very rational 
explanation of suffering and human inequality, seemed to the West be more philosophy than religion. A Buddhism which could be viewed as lacking a numinous in any form bolstered this understanding. It is worth noting also that a second possible force propelling a demystifying apologetic was a desire to keep Buddhism utterly distinct from those numinous-embracing religions which equate numen with deity ... and mystical experience with God-communion and God-awe.

Richard Hayes makes perhaps the strongest attack on the notion of numen as an attribute of Buddhism (Hayes 1988). He begins by taking Rudolph Otto to task for his use of a single monk's emotive description of nirvana in hushed tones as the universal Buddhist perception of nirvana. The monk depicted nirvana as "bliss unspeakable" (Otto 1917, English transl. 1958, p. 39). Otto uses this to declare that Buddhism possesses something sacred and transcendent which inspires awe-in short, a numen. Hayes feels Otto ignored centuries of classic doctrinal descriptions of nirvana which express it as negation (Hayes 1988, pp. 34, 35). Hayes argues that the idea of "awe," which permeates Otto's portrayal of the numinous, is not applicable to Buddhism. In fact, he argues that there is no transcendence in Buddhism at all. Hayes may be right in his critique of Otto's attribution of mysterium tremendum (at least as Otto envisions it) to nirvana, but for most Theravada and Mahayana Buddhists Hayes is vastly overstating his claim when he goes on to say:

Buddhist nirvana, then, is seen not as a transcendence but as an acceptance of our own limitations and frailties and ignorance. Just as nirvana is a conquest of death only in the sense it is an acceptance of death and therefore a conquest of our fear of dying, nirvana is also a conquest of ignorance only in the sense that it is an acceptance of the limitations on our knowledge and therefore a conquest of our fear of being in the dark. (Hayes 1988, p. 35)

Against this, however, is the fact that for the Buddha and most Buddhists there are dramatic changes in state associated with liberation, nibbana/nirvana. ${ }^{3}$ This is true in both of the major branches of Buddhism, despite the fact that their concepts of nirvana are quite different. The doctrinal, metaphysical distinction between the two major divisions of Buddhism regarding nirvana is articulated with exceptional lucidity and brevity by Makransky:

According to the dualistic pre-Mahayana [Theravada] formulation of samsara and nirvana ... realization of the impermanent, selfless, and suffering nature of the psychophysical aggregates (skandhas) deconstructs the epistemological conditions for their being (ignorance and attachment), ultimately culminating in their cessation and the attainment of an unconditioned state (nirvana) that stands apart from the conditioned worlds of living beings ...

In contrast to this, the Mahayana's seminal intuition of emptiness (sunyata) generated a radically different model: the nonduality of samsara and nirvana. ... A Buddha's nirvana was no longer conceived as an unconditional state that stands apart from the conditioned world (nirupadhisesa nirvana), but as the perfect, nondual awareness of the ultimate nature of the world. ... [A] Buddha's nondual 
awareness of the dharmadhatu ["as-it-is-ness" - the true nature of the cosmos]

is an inconceivably vast awareness, an awareness that also comprises, in some sense, a nondual communion with the entire cosmos through its one ultimate nature.

(Makransky 1997, pp. 323, 324)

As Makransky's words above suggest, Buddhism does, in fact, hold a more substantial view of enlightenment and nirvana than Hayes alleges. In Theravada Buddhism the key spiritual gain associated with nibbana is the cessation of samsara, the cycle of rebirth and death. This cycle the Buddha calls "misery." (See Dhammapada 153, 154, quoted below). We may indeed view nibbana as negation, as Hayes suggests; it is the negation of the misery and cycle of samsara. But this is far more than Hayes intends. For him nirvana is merely a negation of fear ... by developing equanimity regarding the realities of our own death and ignorance.

The Buddha's attainment of enlightenment and nibbana in the Pali canon are, at a minimum, supramundane ... and, from the perspective of the common man in just about any culture, supernatural as well. The Buddha not only ceased universal human cravings, but also saw his past lives, and saw the future lives of others (Pali canon, Majjhima Nikaya 1.247-249). Walshe notes that within the pages of the canon nibbana is actually sometimes referred to as "the Supramundane" (Pali lukuttara); he also observes that in this context it is described as lying "beyond the Three Worlds" of "Sense-Desire, Form and Formlessness" (Walshe 2005, pp. 40-42).

Walshe notes as well that nibbana is concurrently called "highest bliss" and "extinction." Extinction is, of course, much closer to Hayes' "negation," but the extinction of what?-merely of certain fears? Walshe certainly sees far more from his reading of the canon. And the apparent paradox between "extinction" and "highest bliss," at least in part, leads him to write: "Very oddly, in the Pali-English Dictionary, it is said that 'Nibbana is ... not transcendental.' In fact it is precisely the one and only transcendental element in Buddhism ... It is ineffable" (Walshe 2005, p. 30). ${ }^{4}$

Harvey also describes the sphere of nibbana as transcendent; he asserts that "Nibbana is beyond the limitations of both earthly and heavenly existence" (Harvey 1990, p. 38). And in thus transcending earth and heaven, nibbana is in a way super-transcendent ... at least as compared to transcendence in the many belief systems which treat heaven and God/gods as the ultimate Other. Ninian Smart distinguishes Theravadin transcendence from other forms of transcendence by emphasizing that it is a state not a being:

There is no use in Theravadin language for such locutions as 'Nirvana is all pervasive or supports the world or is omnipresent. ${ }^{5}$ Nirvana is transcendent in that it is not part of the loka or cosmos... [A]lthough nirvana is the ultimate it is not the ultimate Being or God, but rather the ultimate state, to be classified ordinarily in the Indian tradition as moksa, or salvation or liberation. (Smart, 1996, p. 31)

It is difficult, then, to reject a transcendent, largely ineffable mysterium as not doctrinally present in the Theravada-even if that mysterium is not deity. Whether the transcendent in the Theravada includes tremendum is an issue to which we shall return.

The Mahayana situation is somewhat different. Makransky supports his earlier description of Mahayana distinctives with quotes from several Mahayana sutras. Quoted below 
are two passages, both from just one of the sutras from which Makransky includes excerpts. This sutra is the Avatamsaka Sutra which, according to Cleary, is "perhaps the richest and most grandiose of all Buddhist scriptures, esteemed by all schools of Buddhism that are concerned with ultimate liberation" (Cleary 1993, p. 1). In English translation the sutra is known as the Flower Ornament Sutra.

Avatamsaka Sutra, Book 10, "An Enlightening Being Asks for Clarification"

The realms of beings of the cosmos

Ultimately have no distinction;

Thoroughly knowing all of them

Is the sphere of the enlightened ones.

...

The minds of all sentient beings

In the past, present, and future,

The enlightened [one], in one instant,

Can thoroughly comprehend.

(Avatamsaka Sutra, Cleary's translation 1993, p. 311)

Avatamsaka Sutra, Book 37, "The Manifestation of Buddha"

How should great enlightening beings know the sphere of Buddha, who has realized Thusness and is completely awake? Knowing the spheres of all worlds by means of unobstructed, unimpeded knowledge is the sphere of Buddha. Knowing the spheres of all times, all lands, all things, and all beings, the undifferentiated sphere of True Thusness, the unobstructed sphere of the reality realm, the boundless sphere of absolute truth, the unquantified sphere of space, and the objectless sphere, is the sphere of Buddha. ... Just as the water of the ocean all comes from the mental power of the king water spirit, so too does the water of the ocean of omniscience of all buddhas all come from the buddhas' past vows. The ocean of omniscience is infinite, boundless, inconceivable, and inexpressible ... Buddha instantly knows all things in all times... By knowing all things are natureless, a Buddha attains omniscience, and by great compassion continues to save sentient beings. (Avatamsaka Sutra, Cleary's translation 1993, pp. 1005, 1006, 1009, 1010)

There is in these passages an assertion of the ultimate lack of differentiation of all things. And Harvey confirms that in Mahayana thought there is ultimately no subject-object duality (Harvey 1990); the Mahayana holds what Westerners often treat as a monistic worldview, although the Mahayana scholar himself would use language which emphasizes the commonality of non-essence (sunyata), rather than monistic language, to describe his ontology.

But the above passages from the Avatamsaka Sutra also contain a lot more. While nonduality may characterize the Mahayana accurately and may even lend some legitimacy to Hayes' claim that there is no transcendence (in at least some hues of Buddhism), it can hardly be seen to support the base of his argument. Omniscience, including prophetic omniscience, sweeping clairvoyance, and the capacity to save sentient beings lie in a supramundane sphere that is nothing like Hayes' "acceptance of death" and "acceptance of the limitations of knowledge." Yet these omniscient and redemptive powers are the defining features of Buddhahood and nirvana in the Avatamsaka Sutra.

It is clear then that both major strands of Buddhism view nirvana as something far beyond Hayes' articulation. In both the Theravada and the Mahayana, full enlightenment 
(liberation, nirvana) creates a radical change in the enlightened one's state. In the Theravada this is a state that is transcendentally ineffable. In the Mahayana it is a state of supranormal knowledge which, while it may not be wholly transcendent, sees the ineffable monistic reality of all existence. In the Mahayana nirvana is also a state which enables a supra-normal efficaciousness, dissolving the negative karma of others (known doctrinally as the transfer of merit). ${ }^{6}$ And Makransky is surely correct in giving Mahayana nirvana its full mystical quality by noting that it "comprises, in some sense, a nondual communion with the entire cosmos through its one ultimate nature" (Makransky 1997, p. 324).

\section{An-atman and the numen}

Hoyu Ishida argues on somewhat different grounds from Hayes that Buddhism holds no numen. Specifically, he focuses on the fact that Otto builds certain arguments on the assumption of a permanent soul. Otto declared the numen to be Wholly Other in contrast to the human person/soul; and he also asserted that the capacity to apprehend the numen is an a priori attribute of the human soul. Ishida finds both notions, a Wholly Other and an a priori faculty of numinous perception, to be problematic for much of Buddhism (Ishida 1989). Ishida's argument with regard to the Wholly Other is that because Buddhism denies the existence of a soul, there is nothing against which the numinous can be Other. Similarly, he argues, there can be no a priori knowledge of the numen imbedded in the soul if there is no soul (expressed in Buddhism as "an-at$m a n ")$. Though these claims are clearly related, we will take them one at a time.

From an ontological standpoint Ishida's objection to a Wholly Other is not far from Hayes' ... in that both claim "the other" does not exist in Buddhism. But there is an important nuance. Hayes claims there is no transcendence in Buddhism; Ishida claims that the only thing of substance in Buddhism is the transcendent, the supramundane nirvana. Ishida does not deny that there is something which might be ineffable and inspire awe; rather he denies that the mundane is in any way substantial, or "real" (to use his term) (Ishida 1989, p. 9). Ishida's argument asserts a kind of monism through the insubstantiality of one side of a perceived duality. He writes that "Buddhism includes in its negation of the soul a corresponding negation of the total objectivity and separateness of the divine" (Ishida 1989, p. 9). It is tempting to read into this a meaning of "negation of the separateness of the samsara-bound deities of classic Buddhism." But contextually Ishida is simply using Otto's language to refer to the ultimate. Furthermore, he does not assert the insubstantiality of the ultimate transcendence (as Mahayana "emptiness" might do); he speaks of nirvana as an attaining of salvation and affirms the permanence of this state. His point is not that there is no ultimate reality. It is rather that there is no "that" (numen), since there is no "this" (mundane realm) from which to distinguish "that." He speaks in classic monistic style of a lack of "subject-object distinction" (Ishida 1989, p. 9). His monism is a special case of monism which does not easily align with more traditional Buddhist (i.e., Mahayana) monism. The Mahayana asserts that nirvana and samsara are ultimately one. Both are equally "empty" and the nature of this unitive ultimate reality is "ineffable" (Harvey 1990, p. 111).

What is interesting about Ishida's monism-by-lopsided-permanence is that it is appar-

ently an attempt to formulate a monism which incorporates the Theravada ... though Ishida does not make specific reference to the Theravada. It is difficult to find other 
Eastern writers who have considered monistic-versus-dualistic ontology a subject of much interest, so Ishida stands in lonely territory with his proposition. By contrast we have already noted the view of many Western scholars-well articulated by Harvey, Smart, Makransky, and Walshe-who maintain that the Theravada is dualist. Certainly a robust case can be made that Theravada metaphysics is not consistent with Ishida's monistic assertion, since the world of sense/pleasure/suffering-while impermanent-is not denied true ontological existence (Harvey 1990). But such denial of existence seems to be the thrust of Ishida's argument if taken to its logical terminus; impermanence and non-existence come perilously close to being the same thing. In Theravada Buddhism nibbana is unconditioned, while the sense-world is conditioned-but both are very real.

Ishida's second argument, the argument dealing with Otto's a priori capacity to perceive the numen, lends itself to a simpler disposition. He attributes to Otto the idea that "[ $\mathrm{t}]$ he religious consciousness has its own innate structure and makes use of its own a priori categories," as well as the idea that "the numinous feeling signifies the presence of some particular kind of object, the numinous" (Ishida 1989, p. 5). But in Otto's thought the existence of a numen is in no way dependent on the existence of an a priori capacity to perceive it. As Lopez correctly asserts: "[Otto's] Idea of the Holy is not intended as a philosophical treatise proving the existence of the numinous; rather it is an apology for the intuitive element of religious experience" (Lopez 1979, p. 470). Ishida seems to misconstrue Otto on this issue; he does not quote any specific passage from Otto in support of his reading of Otto on the matter.

The best that can be said is that Otto may have conditioned a numinous awareness/ experience on the a priori capacity to perceive it outside of reason and the senses. If Otto's a-priori notion is, in fact, doctrinally inconsistent with Buddhism, numinous experience is thereby excluded, but not the numinous itself. This exclusion would nevertheless have the effect of making the postmodern expectancy of a felt numen impossible from a Buddhist perspective. But, while Otto presumes a soul as the source of an a priori numinous-encountering capacity, there seems to be no credible argument for rejecting the idea that such a priori capacity could arise within the construct of the five skandas (or aggregates-the five components of conditioned human existence). Certainly the capacity to interact with the sense world arises within the skandas (as does the a priori belief in soulish permanence). In short, Otto's a priori is not incompatible with Theravadin Buddhist understandings of the human psyche.

In the Mahayana, the notion of Buddha-nature may be employed fairly easily as the foundation for an Otto-style instinctual capacity to perceive the numen and even an innate belief in it. And it appears that D. T. Suzuki does just this in Outlines of Mahayana Buddhism. (Suzuki 1908, pp. 25-28, 92, 93) ${ }^{7}$ There seems to be little merit to Ishida's claim that Buddhism bars a numen and a numinous experience simply because it rejects the notion of a permanent soul.

As a final note on the a-priori theory, it is worth observing that Otto's a-priori argument was merely his apology for extra-empirical prehension in religious belief and encounter. For the postmodern there is no need to explain how an extra-rational, extra-sensory capacity to encounter the numinous is acquired-whether by birth, by growth in meditative practice, by the working of karmic law as thoughts and desires are purified, or by some other means; it simply is. In the end, neither the existence nor the perceiving of the numen is dependent on the a-priori theory. 


\section{Experiential transcendence in Buddhism}

But there is more to consider which may be deemed transcendent from the perspective of the experiencer's prehension. We noted earlier that Walshe treated nibbana as the only transcendence in the Theravada. And Smart and Harvey would likely agree that it is the only transcendent object/state in the doctrine of the Theravada (Smart 1996, Harvey 1990). When these scholars assert that nibbana is the only transcendent article in Buddhism, I understand them to be speaking ontologically; this sole transcendence is present in the metaphysics of canon and creed. But the quality of the supramundane, the sense of transcending ordinary experience, attends more than nibbana itself. The jhanas serve as a prime example. Harvey describes the four foundational jhanas as states in which "the mind is blissfully absorbed in rapt concentration on [an] object, and is insensitive to sense-stimuli ... a sort of trance," though not a "stupor" (Harvey 1990, p. 250). Henepola Gunarantana asserts that when the yogin reaches the last of these, the "supramundane jhana of the four paths ... [he] burns up the defilements [hindrances to the apprehension of the true state of things] and attains the liberating experience of the fruits" (Gunaratana 1985, p. 8). This appears to be an experience in which some of the intuitions of nibbana are coming to fruition, though not fully realized. The jhanas, then, may be said to be apprehensions of aspects of ultimate reality, experiences of transcendence, though not final transcendence. This is what I understand the Buddha to be saying when he, as Gunaratana articulates, "refers to the four jhanas figuratively (pariyayena) as a kind of nibbana: he calls them immediately visible nibbana, final nibbana, a factor of nibbana, and nibbana here and now" (Gunaratana 1985, p. 7). Bhikkhu Bodhi writes similarly: "The Buddha calls the jhanas the 'footsteps of the Tathagata' (MN [Majjhima Nikaya] 27.19-22) and shows them to be pre-cursors of the bliss of Nibbana that lies at the end of the training" (Bodhi 2005, p. 227). These descriptions imply a somewhat underdeveloped, but nevertheless substantive, experience of the supramundane. Harvey also describes the jhanas in a way that indicates a clear, if temporary, break from the mundane world; he depicts them as "qualitatively" distinct from and "beyond the realm of the sense-desire world"-and thus, if we may expand on his description, closer to the world of unconditioned ultimate reality (Harvey 1990, pp.250, 251). Gunarantana, in his work The Path of Serenity and Insight: an Explanation of the Buddhist Jhānas, also describes some of the intuitions of a second tier of jhanas that lie beyond the four basic ones-the formless jhanas as they are called, since the meditative "object" is without form. He describes these intuitions as, among other things, seeing the reality in others' minds and possessing the knowledge of prior births and deaths of others. These are again insights into something that is more substantial than the mundane and illusionary sense-world (Gunarantana 2005, pp. 130-133). The jhanas, then, are not merely altered states of consciousness, but states in which certain intuitions of ultimate reality are gained. Finally, Gunaratana records that "in the jhana the whole body is suffused with bliss due to pervasion by rapture, and the pain-faculty then completely ceases, beaten out by the opposition" (Gunaratana 2005, p. 97). This rapturous, painless, "beyond-the-sense-world," nirvanaprecursive state can certainly be considered transcendental experientially.

Many Western scholars have taken a somewhat different approach to the formless jhanas as supramundane experiences. They regard the advanced jhanas of the Pali canon as monistic experiences in a dualist system. We have already noted that Ninian 
Smart (along with other scholars) treats Theravadin Buddhism as dualist. Yet Smart contends that the higher jhanas are experiences of non-duality-driving an experiential Theravadin monism, even though the ontology is dualist. King makes a similar claim in "Mysticism and Spirituality" (King 2005, p. 315), as does Wainwright in Mysticism: A Study of Its Nature, Cognitive Value and Moral Implications (Wainwright 1981, p. 228). Smart is particularly forceful in his assertion that the dualist Theravadin ontology gives way to monistic experience:

The assent of the jhanas ... culminat[e] in the realization of certain formulae such as 'There is nothing.' There is no ... fascination with any phenomenological object [in these higher jhanas].... The contemplative experience ... abolishes the distinction between subject and object: most comprehensively in the Theravada. (Smart 1996, p. 29)

Assuming for the moment that Smart's portrayal is accurate, his argument implies that the Buddha and other jhana adepts experienced strongly unitive intuitions in the higher absorptions. Such intuitions would make the higher jhanas the Eastern companions of many Christian and Sufi mystical encounters. Western unitive experiences are among the most profoundly ineffable encounters recorded by the mystics of those traditions ... despite the vigorous dualist ontologies which underlie the traditions. This assertion by Smart stands on soft ground, however, for Theravadins themselves appear generally to maintain that the higher absorptions are simply experiential an-atmanism, not monism. Yet even a true experience of an-atman approaches mysterium tremendum for most of us; it is the experience of a state incomprehensible to our native state of being, the total absence of "I."

In recognizing some altered states of consciousness, such as jhana, as transcendental, it is important to observe that there are degrees of the ultimacy of transcendence in the mind of the experiencer. The experiencer may well recognize doctrinally that he is not experiencing the absolute ultimate. Many mystics understand that they are experiencing a representative or symbol of the ultimate-something much closer to it than the everyday, mundane world is capable of yielding, but not yet the absolute. The anonymous, mystic Christian author of The Cloud of Unknowing (fourteenth century) recognizes that his "cloud" is not God, but "very near to God." (The Cloud c. 1375, Ch. 4; referenced as (Anonymous) 2000) Yet these cloud events were perceived as transcendental, numinous, by the author. It is this experiential prehension that establishes an event as transcendental in the mind of the one who encounters it. Stated in another way, as a human experience, the perception of supramundaneness gives rise to the consciousness of encounter with the transcendent ... the ontology (or lack thereof) of the "transcendent" object/state seems practically irrelevant from this standpoint. Ontology, I submit, is relevant primarily to the extent that the experiencer's belief in the article as transcendent lends force to the sense of supramundaneness, of mysterium. But such belief need not be present at all for the altered state of consciousness to be experienced as transcendental. The fact that the jhanas are not experiences of the final and only ontologically transcendent state in the Theravada (nibbana), and the concurrent fact that the experiencer knows they are not, should not impair them as experiences of the supramundane-of something transcendent, something which approximates or gives the sense of the ultimate. And the Buddha seems to acknowledge this attribute of the jhanas when he calls them "figurative" encounters of nibbana (Gunaratana 1985, p. 7). 
Furthermore, if the jhanas are indeed experientially numinous, then the Buddha may be considered a mystic by the standards of postmodern spirituality. The Pali canon records in the Majjhima Nikaya (1.247-249) the account of Gautama Buddha passing through each of the four foundational jhanas as an immediate prelude to his enlightenment. Moreover, the Digha Nikaya of the Pali canon indicate that " $\mathrm{t}]$ hroughout his career the four jhanas remained 'his heavenly dwelling' (dibbavihara) to which he resorted to live happily here and now." (Gunaratana 1985, p. 6)

Turning now to the Mahayana, it must once again be approached somewhat differently, since it is essentially monistic ontologically. Its ontology of monism does not, however, restrain an everyday, everyman tenacious sense of duality among Mahayanists. This mundane sensation implies that transcendence can be perceived experientially even though it may not exist doctrinally/ontologically. Indeed, the radical Buddhahood state of comprehending the cosmos as unitary is itself likely to give the sense of transcendence; this state of knowing is clearly supramundane, mysterium. The condition of the human being which Buddhism at its core seeks to address, indeed counter, is the powerful perception of self as a permanent ontological structure. The strong illusion of enduring self leads to the perception of the True Monistic Condition of the Cosmos as Other. This Other transcends the adherent's normal-experience world, just as the jhanas transcend the Theravadin's normal-experience world. Once the True Monistic Condition of the Cosmos is actually apprehended it is no longer Other. But it is altogether Other on the journey ... until the very last step at the summit. And when the Monistic Cosmos ceases to be Other it is still initially transcendent, wholly beyond the mundane world. Only with the familiarity of time does it cease to be transcendental experientially, if at all. In Mahayana thought this is the nirvana which Gautama Buddha reached, the summit of a mystical journey.

\section{Vicarious transcendence in Buddhism}

There is yet another category of experiences which may be classified as possessing transcendence. These are experiences which the experiencer may not consider transcendent at all, but which to the common adherent are transcendent. The Theravada canon records many encounters of the Buddha and some of his closest monks with gods/devas. ${ }^{8}$ Perhaps the most well-known is the encounter of the Buddha with Brahma Sahampati of the Brahma class of gods (the highest class). Brahma Sahampati was concerned that the Buddha was considering a non-teaching life and entreated him to share his enlightenment with the world so others might also walk the path to liberation (Harvey 1990, p. 22). In these encounters with gods, the Buddha is the spiritually superior being whether the gods visit him or he visits them. But regardless of who held the superior position spiritually or who initiated the encounter, from the perspective of the vast majority of Theravadin Buddhists (who approach these accounts with an historical-literal hermeneutic) these are experiences of something that is clearly supramundane ... the Buddhist theology that places the gods in samsara notwithstanding. The interactions with the gods may have been mundane for the Buddha, but to the lay Theravadin these canonized experiences are transcendent and undoubtedly help authenticate the Buddha's direct knowledge of true nature of the universe-its metaphysics and cosmology. In sum, there is in the Theravada that which is doctrinally transcendent and thus mysterium, that which is experientially supramundane and thus mysterium, and that which is recorded as sacred and vicariously sensed as supramundane and thus mysterium. 
In the Mahayana, with its monistic worldview, it is primarily the vicarious transcendent that gives substance to Gautama Buddha's attainments of enlightenment and nirvana as direct encounters of the "ultimate" state ... despite the fact that doctrinally there is no clean transcendence. For Mahayana aspirants, the Buddha's attainments profoundly transcend their own experience, their mundane state of being. In the Mahayana the ultimate state, which was achieved by Gautama Buddha, includes: 1) seeing beyond the impression of duality to the true Monistic Condition of the Cosmos, 2) a vast omniscience that accompanies this insight, and 3) powerful supernormal redemptive capacity to liberate others from that which hinders their attainment of nirvana. All aspects of this state are vicariously transcendent.

\section{Tremendum in Buddhist experience}

We move now to the question of whether tremendum may be said to be present in Buddhism and to have been experienced by the Buddha. Hayes, we have noted, asserts that there is nothing of awe in Buddhism. If this be so then the widely held understanding of Dhammapada 153 and 154 as the Buddha's words upon reaching enlightenment is surely in error. It appears he experienced a deep sense of emotive release, or as Harvey describes it, "joyful exaltation," at the Enlightenment. (Harvey 1990, p. 22)

Dhammapada 153, 154 reads:

I ran through samsara, with its many rebirths,

Searching for, but not finding, the house-builder.

Misery is birth again and again.

House-builder, you are seen!

The house you shall not build again!

Broken are your rafters, all,

Your roof beam destroyed.

Freedom from samsara has the mind attained,

To the end of cravings has it come.

(John Ross Carter \& Mahinda Palihawadana translation)

The Buddha's words convey an impression of gentle euphoria, awe, at the tranquility of this emancipation from samsara. Further, if Henepola Gunaratana's understanding of the Digha Nikaya, ${ }^{9}$ which we considered earlier, is correct, it is hard not to see in the Buddha's frequent return to the jhanas during his post-enlightenment career a powerful emotive quality of the joy of the supramundane. According to Gunaratana these returns were the fully enlightened Buddha's "heavenly dwelling' (dibbavihara) to which he resorted to live happily here and now" (Gunaratana 1985, p. 6). Gunaratana and Bhikkhu Bodhi also understand the Pali canon to refer to nibbana and the jhanas at times as "bliss" and "rapture." (Gunaratana 1985, p. 97; Bodhi 2005, p. 227) Walshe also, in the Introduction to The Long Discourses of the Buddha: a Translation of the Digha Nikaya, notes that "at Dhammapada 204 and elsewhere [nibbana] is called 'highest bliss"' (Walshe 2005, p. 30). The joy of the supramundane surely approaches tremendum if it is not its precise equivalent.

Hayes discards the tremendum because he believes there is no ontological transcendence in Buddhism ... and thus nothing to inspire awe, bliss, euphoria. More often the 
tremendum is rejected as non-Buddhist because Otto described the tremendum, in part, as "creature-feeling" (Otto 1917, English transl. 1958, pp. 8-10). Of course, there can be no creature (and presumably no creature-feeling) if there is no creator-a postulate Buddhism maintains. But it takes only a little imagination to modify Otto slightly or to emphasize other aspects of Otto's definition to find applicability in Buddhism. No doubt Otto can be criticized for an overly Western perspective-but, like the theories of any notable thinker, due diligence rests in fleshing out the theory where he has not given it sufficient applicative thought. Otto also describes tremendum as "a depreciation of the subject in his own eyes [vis-à-vis the] object" [italics his] (Otto 1917, English transl 1958, p. 11). Detached from the notions of creature and creator as subject and object, this could certainly apply in Mahayana Buddhism to a devaluation of the practitioner's sensation of his existence as an independent entity in contrast to his mystical intuition of the vast monistic reality. And a Theravadin may experience tremendum in some of the other ways in which Otto describes it. Otto portrays tremendum as a sense of intense valuation of the numen in contrast to the mundane; it is a "feeling of being ... dust and ashes and nothingness;" it is "consciousness of being conditioned" [italics his] (Otto 1917, English transl. 1958, pp. 15, 20). These serve as an apt description of the an-atman experience of the formless jhanas. The Theravadin may taste his "dust and ashes and nothingness" (impermanence) and feel the "consciousness of being conditioned," in contrast to the greatness of the permanent and unconditioned nibbana.

We should observe in passing that there is a very distinct conceptual separation between East and West on the issue of ultimate liberation-it is a separation which requires that tremendum feelings be understood somewhat differently in an Eastern context. In the monotheisms the foundational ontological outlook prevents an ultimate, wholesale, eternal and actual merging with the numen. Therefore, in the West, one may, even in the final salvific state, experience tremendum in the presence of the numen. By contrast, in the East (in both Hinduism and Buddhism), becoming part of the numen is the final salvific state. There can be no tremendum in this ultimate liberated state. But short of that state, the Hindu and the Buddhist alike are able to experience the awe of that which they still work to achieve and which they can only glimpse in mystical vision.

Ultimately what Otto is getting at is an affective impact from the recognition of mysterium, from encountering the supramundane. Exhilaration, awe, in the presence of the profoundly extraordinary is an entirely expected psychological response. There is nothing in Buddhism to discourage such a response; it is merely the clinging to such an emotion that the Buddha would have found a hindrance. In the Theravada, as we have seen, awe appears to have been the Buddha's reaction to reaching the supramundane, ineffable nibbana of the now.

The Mahayana possesses its own ineffable pinnacle. Its monistic view of samsara and nirvana as ultimately undifferentiated is certainly ineffable, but is it awe-inspiring or bliss-inspiring as a result? Does it carry tremendum when fully apprehended? D. T. Suzuki certainly understood it to be such and discusses it at length in Outlines of Mahayana Buddhism. He first notes that "nirvana" is a deeply textured word in the Mahayana. He writes that, among other meanings: "it signifies ... a state of consciousness that follows from the recognition of the presence of the Dharmakaya ${ }^{10 "}$ (Suzuki 1908, p. 342). Suzuki sees bliss unmistakably associated with this full enlightenment, this recognition of the Dharmakaya: 
In order to reach the highest truth we must plunge our whole being into a region where absolute darkness defying the light of intellect is supposed to prevail. ... [T] he only way that leads us to the final pacification of the heart-yearnings is to go beyond the horizons of limiting reason and resort to faith ... And by faith I mean Prajna (wisdom), supramundane knowledge, that comes direct from the intelligence-essence of the Dharmakaya. A mind, so tired in vainly searching after truth and bliss in the verbiage of philosophy ... finds itself here completely rested ... - whence this is, it does not question, being so filled with supramundane blessings which alone are left. Buddhism calls this exalted spiritual state Nirvana ... The illumination thus gained in our consciousness constitutes the so-called parinispana [perfected true nature], the most perfect knowledge, that leads to Nirvana, final salvation and eternal bliss. (Suzuki, pp. 91-94)

Thus it is that, while tremendum may not accompany every apprehension of the transcendent (whether ontological, experiential, or vicarious) in Buddhism, it appears that in much, if not most of such experiences, it is present nonetheless.

\section{Summary and conclusion}

I have sought to demonstrate that both the Theravada and the Mahayana possess states which may rightly be understood and apprehended as numinous. I employed Hayes' and Ishida's counterarguments as a kind of base camp from which to start the climb toward that conclusion. Their concerns provided a resistive pedestal on which to build our inquiry of what Buddhism has historically held ontologically ... and, perhaps more importantly, what Buddhism contains that might direct us to mysterium tremendum as a functional reality embedded in the intersection of normal human psychological tendencies with Buddhist teaching and practice. Numinous awareness, I have maintained, is more about impression and non-creedal epistemic influences than formal ontology. Given this backdrop, I do not feel we should have any difficulty in locating a numen in Buddhism. And once such a peak has been identified, the panorama opens also on the Buddha's jhana experiences as mysticism ... at least as most postmodern spiritual seekers would define mysticism.

These two elements of enchantment in Buddhism, a numen and a mystic exemplar-complemented by Buddhism's deep ethical stance-make Buddhism ripe for postmodern spiritual inquiry. Yet, outside of its ethical dimension, Buddhism seems to have gotten little traction within Western postmodern spirituality. It core doctrines have not yet found fertile ground among postmoderns. This trend appears to hold to some extent even where constructive postmodernism has garnered devotees in the East (Fan and Wang 2012; Tang 2015). ${ }^{11}$ A minor exception is the interest in Buddhism evident among some Whiteheadian theologian-philosophers who also identify as postmodern; they view Buddhist doctrine as a religious instantiation of process-theory (Griffin 1990, Cobb 2012). But their reflections are generally far too heady and abstruse for everyday postmodern spiritual seekers. The short of the matter is that Buddhism's foundational metaphysical and doctrinal essence has not been given much consideration within vernacular postmodern spirituality. This is likely the result, in part at least, of the twentieth-century apologetic efforts to extract Buddhism from the domains of numinous religion and mysticism, indeed, to desacralize it altogether (Cobb 2002). ${ }^{12}$ The demystifying apologia, which helped Buddhism find its place in the modern West, may now be hindering it from taking a seat 
at the open table of postmodern spirituality. From an Eastern perspective, a Western spirituality which is ready to comprehend Buddhism as sacred tradition, including its substantive epistemic commitments, is a West more capable of embracing the fullness of Buddhist dharma than the West of modernity was able to do.

\section{Endnotes}

${ }^{1}$ Early texts articulating the idea of a postmodern spirituality, such as David Ray Griffin's Spirituality and Society: Postmodern Visions, began appearing in the late 1980's, but the groundswell seems to have in the 1990s (Benedikter \& Molz, 55-62). In his work, Griffin correctly labeled deconstructive postmodernism, "ultramodernism"-given its rejection of the possibility of coherent worldviews and its tendencies toward nihilism and extreme relativism. (Griffin, $\mathrm{x}$ )

${ }^{2}$ "Distinctives" is used to describe the features (in this case doctrines and worldview) which distinguish a belief system from other related religious forms, primarily Theravada Buddhism in this case.

${ }^{3}$ My convention in this paper assumes that nirvana may now be treated as an English word, but that nibbana is not sufficiently well-known to have become an English word.

${ }^{4}$ For students of Kant, Walshe's use of "transcendental" deviates from Kantian usage. Kant, who sought to distinguish "transcendent" and "transcendental," would have used "transcendent" in this context. Transcendence, transcendent, and transcendental-the use of these terms is complex and has sparked considerable discourse over the years. In this discussion, I will use "transcendent" and "transcendental" in what I understand to be their Kantian senses: "[Kant] set the term transcendental in opposition to the term transcendent, the latter meaning 'that, which goes beyond' (transcends) any possible knowledge of a human being. ... [He] equated transcendental with that which is [related to] the subject's faculty of cognition." (New World Encyclopedia, http:// www.newworldencyclopedia.org/entry/Transcendence_\%28philosophy\%29). By this I understand "transcendent" to refer to the (presumed) ontological reality of some thing or state beyond human comprehension (supramundane and unknowable), while "transcendental" is applied to experiences in which one apprehends the supramundane and unknowable in a non-rational and subjective way. "Transcendence" is used to mean the quality of being transcendent, not the quality of being transcendental.

${ }^{5}$ Smart implies, however, that these descriptions/attributes might be acceptable in the Mahayana.

${ }^{6}$ Transfer of merit is also prominent in the Theravada, though it appears to be primarily a current-life activity (rather than an activity in/of/from nibbana). (Harvey, pp. 42-44)

${ }^{7}$ Suzuki does not use the term "Buddha-nature." However, his understanding is that humanity's religious impulse is inherent in our nature and when stripped of illusions is a pure thing which inherently sees ultimate reality. And the fact that this approach stems from the notion of Buddha-nature is not lost on other Buddhist scholars. See, for example, Dharmachāri Nāgapriya, "Poisoned Pen Letters? D.T. Suzuki's Communication of Zen to the West." Western Buddhist Review. Vol 5 (Oct 2010), p. 7 in PDF.

${ }^{8}$ See Samyutta Nikaya I.1.1-II.1.8 for a specific example. See also the Parabhava Sutta for an excellent example of gods visiting the Buddha to learn from him

${ }^{9} \mathrm{He}$ cites "DN 3-220" which appears to be a defective citation-possibly 3:220? 
${ }^{10}$ Dharmakaya is notorious difficult to translate; "ultimate truth body," "essence of the cosmos," "unity-of-all-things body" are some of the suggestions for English translation.

${ }^{11}$ Tang tends to focus on the ethical-social values of Buddhism as useful to neo-Guoxue, minimizing its religious, epistemic distinctives. This ethical-social emphasis is unquestionably evident in Fan and Wang's treatment of constructive postmodernism in China.

${ }^{12}$ While Cobb acknowledges this point, he tends to attribute the demand for transcendence to the West's theistic roots. But I am unconvinced. Postmodern spirituality is far more a reaction to scientism's demystification of life and cosmos, than its atheism.

\section{Competing interests}

The author declares that he has no competing interests.

Received: 19 October 2015 Accepted: 1 December 2016

Published online: 05 December 2016

\section{References}

(Anonymous). 2000. The cloud of unknowing. Grand Rapids: Christian Classics Ethereal Library. (originally published c. 1375). Armstrong, Karen. 2009. The case for God. Toronto: Alfred A. Knopf, Random House.

Benedikter, Roland, and Markus Molz. 2012. The rise of neo-integrative world views: towards a rational spirituality for the coming planetary civilization? In Critical realism and spirituality, ed. Mervyn Hartwig and Jamie Morgan, 29-74. New York: Routledge.

Bodhi, Bhikkhu. 1998. Review of Buddhism without beliefs, Stephen Batchelor, 1997. Journal of Buddhist Ethics. 5: 14-21.

Bodhi, Bhikkhu. 2005. In the Buddha's words: an anthology of discourses from the Pali canon. Somerville, MA: Wisdom Publications.

Cleary, Thomas, transl. 1993. Flower ornament scripture: a translation of the Avatamsaka Sutra. Boston: Shambhala Publications.

Cobb, John. 2002. Postmodernism and public policy: reframing religion, culture, education, sexuality, class, race, politics, and the economy. Albany: State University of New York.

Cobb, John. 2012. Preface. In Religions in the making: Whitehead and the wisdom traditions of the world, ed. John Cobb, xi-xix. Eugene, OR: Cascade Books.

Fan, Meijun, and Zhihe Wang. 2012. In A Chinese perspective: stimulus to recovery of tradition. Religions in the making: Whitehead and the wisdom traditions of the world, ed. John Cobb, 157-179. Eugene: Cascade Books.

Griffin, David Ray. 1988. Spirituality and society: postmodern visions. Albany: State University of New York.

Griffin, David Ray. 1990. Introduction. In Sacred interconnections: postmodern spirituality, political economy, and art. E. Griffin, David Ray. Albany: State University of New York.

Gunaratana, Henepola. 1985. The path of serenity and insight: an explanation of the Buddhist jhannas. Delhi: Motilal Banarsidass Publishers.

Harvey, Peter. 1990. An introduction to Buddhism: teachings, history and practices. Cambridge: Cambridge University Press. Hayes, Richard. 1988. Dignaga on the interpretation of signs. Norwell, MA: Kluwer Academic Publishers.

Ishida, Hoyu. 1989. Otto's theory of religious experience as encounter with the numinous and its application to Buddhism. Japanese religions 15.3: 19-33. Also available as a separate print at http://www.office.usp.ac.jp/ klinger. w/class/jcmu/Ishida-Otto.pdf, paginated 1-9. The references to Hoyu Ishida in this article follow the pagination of this separate print.

King, Richard. 2005. Mysticism and spirituality. In The Routledge companion to the study of religion, ed. John Hinnells, 306-322. New York: Routledge.

Lopez Jr., Donald S. 1979. Approaching the numinous: Rudolph Otto and Tibetan tantra. Philosophy East and West 29: 467-476.

Makransky, John. 1997. Buddhahood embodied: sources of controversy in India and Tibet. Albany: State University of New York Otto, Rudolph. 1958. The idea of the holy. transl. Harvey, John. London: Oxford University. (originally published in German, 1917).

Raschke, Carl. 2008. GloboChrist: The great commission takes a postmodern turn. Grand Rapids: Baker Academic.

Smart, Ninian. 1996. Dimensions of the sacred: An anatomy of the world's beliefs. Berkeley: University of California Press. Suzuki, D.T. 1908. Outlines of Mahayana Buddhism. Chicago: Open Court Publishing.

Tang, Yijie. 2015. Confucianism, Buddhism, Daoism, Christianity and Chinese culture. Berlin: Foreign Language Teaching and Research Publishing \& Springer-Verlag.

Wainwright, William. 1981. Mysticism: a study of its nature, cognitive value and moral implications. Brighton: Harvester Press.

Walshe, Maurice. 2005. The long discourses of the Buddha: a translation of the Digha Nikaya. Boston: Wisdom

Publications. 